were included in the analysis. Elwood et al. found that women with a haemoglobin below $10.5 \mathrm{~g} / 100 \mathrm{ml}$ had a cholesterol value that on the average was $30 \mathrm{mg} / 100 \mathrm{ml}$ lower than in women with normal haemoglobin values. By using the regression equation in Table III for women aged 20-54 it can be calculated that a lowering of the haemoglobin from a normal of $14 \mathrm{~g} / 100 \mathrm{ml}$ to a low normal of $11 \mathrm{~g}$ would mean a decrease in the cholesterol value of $18 \mathrm{mg} / 100 \mathrm{ml}$, a figure of the same order of magnitude as that of Elwood et al. The same correlation was found for serum triglyceride values. The relation was also found in men both for cholesterol and for triglyceride, a finding not previously reported.

The variations in serum lipid values with the haemoglobin levels previously seen in anaemia have not been explained. They may, of course, be coincidental and largely independent of each other. As pointed out by Elwood et al., 1970, possibly the lower haemoglobin levels in women might be connected with lower serum lipid values, and this could partly explain the lower incidence of ischaemic heart disease in premenopausal women and of people in developing countries.

Possibly part of the relation between cholesterol and haemoglobin values in women, now extended to include also triglycerides, and men may be explained by changes in plasma volume. If we assume that the blood volume remains unchanged as the haemoglobin in women decreases from $14 \mathrm{~g}$ to $11 \mathrm{~g} / 100$ $\mathrm{ml}$, as quoted above, the packed cell volume would decrease from 40 to $32 \%$ and thus the plasma volume would increase from 60 to $68 \%$. If in women the total plasma pool of cholesterol and triglycerides were unchanged and the concentration of cholesterol was $250 \mathrm{mg} / 100 \mathrm{ml}$ and triglycerides of $1.10 \mathrm{mmol} / 1$. with a packed cell volume of $40 \%$, the values would decrease to $220 \mathrm{mg} / 100 \mathrm{ml}$ and $0.97 \mathrm{mmol} / 1$. if the packed cell volume went down to $32 \%$. Thus a change in plasma volume could be predicted to lower serum cholesterol and triglyceride values by
$30 \mathrm{mg} / 100 \mathrm{ml}$ and $0.13 \mathrm{mmol} / \mathrm{l}$. respectively. From the equations in Table III the corresponding figures can be calculated to be $18 \mathrm{mg} / 100 \mathrm{ml}$ for cholesterol and $0.13 \mathrm{mmol} / \mathrm{l}$. for triglycerides.

Assuming unchanged total plasma pools corresponding figures for men would be by calculation $30 \mathrm{mg} / 100 \mathrm{ml}$ and $0.19 \mathrm{mmol} / 1$. and by the regression equation (Table III) $14 \mathrm{mg} / 100 \mathrm{ml}$ and $0.37 \mathrm{mmol} / \mathrm{l}$. Though many assumptions are involved and there are great standard errors in the equations the values obtained by calculation, assuming unchanged plasma pools, are much the same as those obtained by applying the regression equation. Hence simple changes in plasma volume may in part account for the positive correlation between haemoglobin and plasma lipids. This new hypothesis is further substantiated by the findings of Rifkind and Gale (1967), who showed that the decrease in serum cholesterol and phospholipids was not due to a specific lowering of any one of the serum lipoprotein families but was caused by a proportionate fall in all three of the major lipoprotein families, a finding which is indeed compatible with a plasma volume dependent effect.

\section{References}

Böttiger, L.E., and Carlson, L.A. (1972) Skandia International Symphosia. In press.

Böttiger, L. E., and Svedberg, C. A. (1967). British Medical fournal, 2, 85. Carlson, L. A., and Lindstedt, S. (1968). Acta Medica Scandinavica, Suppl.,

Dawber, T. R., and Kannel, W. B. (1961). Modern Concepts of Cardiovascular Disease, 30, 671 .

Elwood, P. C., Mahler, R., Sweetnam, P., Moore, F., and Welsby, E. (1970). Lancet, 1, 589 .

Erben, F. (1902). Zeitschrift fur klinische Medizin, 47, 302.

Hashmi, J. A., et al. (1969). Fournal of the Pakistan Medical Association, 19, 131 .

Rifkind, B. M., and Gale, M. (1967). Lancet, 2, 640

Snedecor, G.W. (1956). Statistical Methods. Ames, Iowa, Iowa State College.

\title{
Serum Enzyme Levels in Diagnosis of Postoperative Myocardial Infarction
}

\author{
SYLVIA M. WATKINS, ADAM LEWIS
}

British Medical fournal, 1972, 3, 733-735

\section{Summary}

The levels of creatine kinase, hydroxybutyric dehydrogenase, and aspartate transaminase have been serially measured in the serum of patients undergoing surgery. Serum enzyme levels often rose to a range commonly found after myocardial infarction but fell to normal within 5-10 days. Raised serum enzyme levels have no diagnostic significance in a case of postoperative chest pain until after the fifth postoperative day, but may be significant thereafter.

\section{Introduction}

The differential diagnosis of chest pain in patients who have recently undergone chest or abdominal surgery is apt to be difficult; pain due to inflammatory lesions of the lungs or pleura, to surgical trauma, or to myocardial or pulmonary infarction may all produce similar symptoms. Raised levels of certain

Royal Free Hospital, London N.W.3

SYLVIA M. WATKINS, B.M., M.R.C.P., Senior Medical Registrar ADAM LEWIS, F.R.c.s., Senior Surgical Registrar serum enzymes occurs in some cases of pulmonary infarction (Henley, Schmidt, and Schmidt, 1966; Mullan, 1969) and in $90-97 \%$ of cases of myocardial infarction (Agress, 1959; Henley et al., 1966). These changes may precede any abnormality in the electrocardiogram by up to several days (Wood, 1968; Mullan, 1969), and serum enzyme estimations are therefore very valuable in the early diagnosis of myocardial infarction. Operative injury, however, may also result in the release of these same enzymes from the damaged tissues (especially skeletal muscle) into the circulation (Lawrence and Schulkins, 1956; Watanabe, Kaltus, and Semenson, 1957; Henley et al., 1966). Hence in the early postoperative period raised levels of serum enzymes are not necessarily significant in the diagnosis of myocardial infarction.

In order to establish the extent and duration of changes in serum enzyme levels due to operative injury the levels of aspartate transaminase, hydroxybutyric dehydrogenase, and creatine kinase were serially measured in the serum of patients undergoing a variety of surgical procedures.

\section{Patients and Methods}

Routine "cold" surgical patients undergoing thoracic or abdominal operations were studied. Aspartate transaminase, hydroxybutyric dehydrogenase, and creatine kinase were esti- 
mated preoperatively and postoperatively at 24 hours and 3, 5, 7 , and 10 days. Electrocardiography was performed preoperatively and on the seventh postoperative day. Patients were excluded from the study if the preoperative enzymes were raised (one case), if the electrocardiogram was abnormal preoperatively or postoperatively (one case), or if there was any clinical evidence of deep-vein thrombosis or myocardial or pulmonary infarction (one case). The patients were otherwise unselected.

Fourteen patients aged 29 to 78 were included in the study; 4 underwent thoracotomy, 3 cholecystectomy, 3 vagotomy and pyloroplasty, 2 partial gastrectomy, 1 colectomy, and 1 suprapubic prostatectomy.

The aspartate transaminase and hydroxybutyric dehydrogenase levels were estimated using spectrophotometric methods (Rosalki and Wilkinson, 1960; Bergmeyer and Bernt, 1965; Laudahn, Hartmann, Rosenfeld, Weyer, and Muth, 1970) and creatine kinase levels by a colorimetric method (Hughes, 1962). By these methods the normal range for aspartate transaminase is 4-15 IU/l., for hydroxybutyric dehydrogenase 50-150 IU/l., and for creatine kinase 4-60 IU/1.

\section{Results}

The results are summarized in Figs. 1, 2, and 3, and in the Table. In 10 patients there was a rise of all three enzymes, maximum levels being attained on the first or third postoperative

Range of Enzyme Levels and Peak Rise in Activity after Operation. Results Range of Enzyme
expressed in $I U / l$.

\begin{tabular}{|c|c|c|c|c|c|c|}
\hline & & & & $\begin{array}{c}\text { Aspartate } \\
\text { Transaminase }\end{array}$ & $\begin{array}{l}\text { Hydroxybutyric } \\
\text { Dehydrogenase }\end{array}$ & $\begin{array}{c}\text { Creatine } \\
\text { Kinase }\end{array}$ \\
\hline $\begin{array}{l}\text { Preoperative } \\
\text { Postoperative: }\end{array}$ & . & .. & . & $6-14$ & $50-150$ & $15-59$ \\
\hline 24 hours .. & . & . & .. & $7-62$ & $60-336$ & $89-550$ \\
\hline $\begin{array}{l}3 \text { days } \quad . \\
5 \text { days }\end{array}$ & $\cdots$ & $\cdots$ & $\cdots$ & $\begin{array}{l}6-56 \\
9-44\end{array}$ & $\begin{array}{l}90-406 \\
71-145\end{array}$ & 43-535 \\
\hline 7 days $\quad$. & $\therefore$ & $\therefore$ & $\therefore$ & $\begin{array}{r}9-44 \\
10-23\end{array}$ & $\begin{array}{l}71-145 \\
86-155\end{array}$ & $\begin{array}{l}27-330 \\
27-67\end{array}$ \\
\hline 10 days $\ldots$ & . & .. & . & $13-20$ & $95-150$ & $18-35$ \\
\hline
\end{tabular}

Normal ranges are given in the text.

day in most cases, thereafter falling again to normal levels within a few days. The range of enzyme levels postoperatively was very large, and in four patients (two vagotomy and pyloroplasty, one cholecystectomy, and one prostatectomy) there was only a slight rise in creatine kinase, while the aspartate transaminase and hydroxybutyric dehydrogenase remained within normal limits throughout the period of study. In general, the highest postoperative rises in enzyme levels were seen in patients who had the most extensive operative trauma (thoracotomy patients).

\section{Discussion}

These results show that there is a rise and subsequent fall of these three serum enzymes in most cases after surgery. Our findings are consistent with those of Watanabe et al. (1957) and Lawrence and Schulkins (1956), who found rises in transaminases after major operations. Schlief and Kamm (1957) observed rises in transaminase and lactic dehydrogenase after heart surgery, and equated this finding with the enzyme changes occurring after myocardial infarction. Raised transaminase levels have also been found within minutes of experimental burns in rats (Spector and Pauli, 1963).

On the other hand some workers found raised transaminase levels only after certain operations, including biliary tree surgery (Person and Judge, 1958; Rehn, Koehnlein, Graner, and Zeller, 1960), liver biopsy or manipulation, extensive trauma to skeletal muscle, large postoperative abscess or haematoma, pulmonary resection, and possibly prolonged anaesthesia (Person and Judge, 1958), though Lawrence and Schulkins (1956) found no difference when either general or spinal anaesthesia was used. Rehn et al. (1960) found no rise in enzyme levels after a variety of other operations including splenectomy, prostatectomy, herniorrhaphy, appendicectomy, and renal surgery. Henley et al. (1966) stated that enzyme changes postoperatively were, "absent or slight," and Person and Judge (1958) felt that in most cases the enzyme changes were too small to cause diagnostic confusion.

Our results showed that in some cases postoperative enzyme levels were within the range often found after myocardial infarction (Elliott and Wilkinson, 1962; Henley et al., 1966), though the average time course differed slightly from that after myocardial infarction. In every case in the present series the hydroxybutyric dehydrogenase had returned to normal within five days of operation, the creatine kinase within seven days in 13 of the 14 patients, and by 10 days all the aspartate transaminase levels were below $20 \mathrm{IU} / 1$., and most were within the normal range. Raised levels of the relevant serum enzymes within these postoperative periods must therefore be interpreted with great caution. After the fifth postoperative day, however, raised serum enzyme levels become progressively more useful in the diagnosis of chest pain.

We wish to thank Mr. George Qvist for his interest and support, and the biochemistry and electrocardiography departments for technical help.

\section{References}

Agress, C. M. (1959). American fournal of Cardiology, 3, 74

Bergmeyer, H.-U., and Bernt, E. (1965). In Methods of Enzymatic Analysis, ed. H.-U. Bergmeyer. New York, Academic Press.

Elliott, B. A., and Wilkinson, J. H. (1962). Lancet, 2, 71. Henley, K. S., Schmidt, E., and Schmidt, F. W. (1966). Enzymes in Serum.
Springfield Illinois, Thomas.
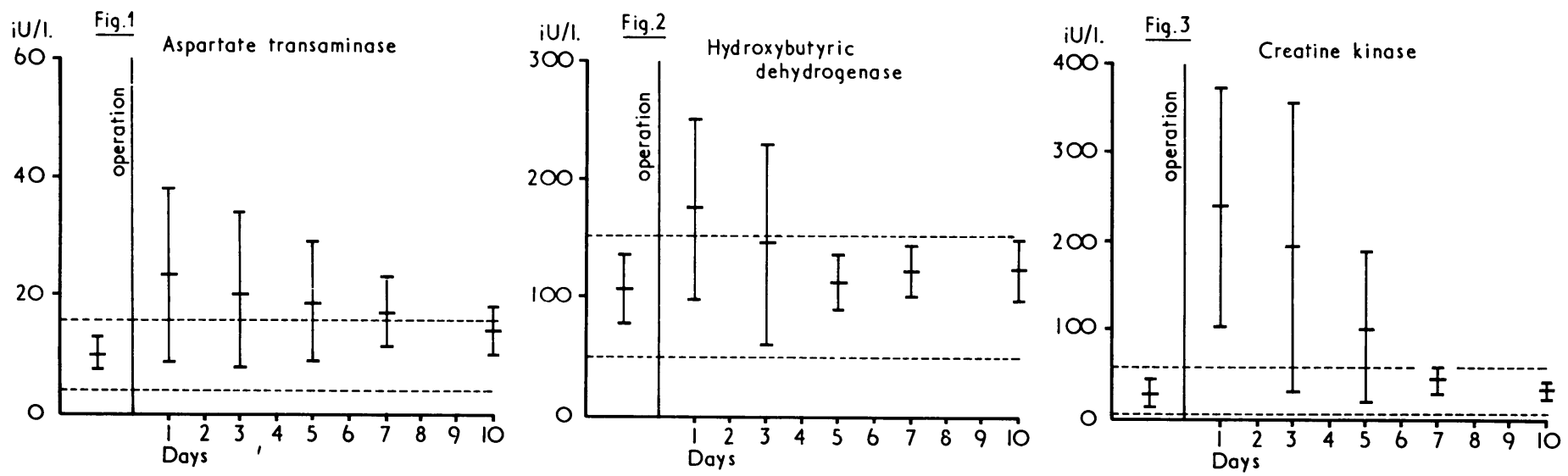

FIG. 1 Normal limits of aspartate transaminase levels and mean levels ( \pm 1 S.D.) before and after surgery. FIG. 2-Normal limits of hydroxybutyric dehydrogenase levels and mean levels ( \pm 1 S.D.) before and after surgery. FIG. $3-$ Normal limits of creatine kinase levels and mean levels ( \pm 1 S.D.) before and after
surgery. 
Hughes, B. P. (1962). Clinica Chimica Acta, 7, 597.

Laudahn, G., Hartmann, E., Rosenfeld, E. M., Weyer, H., and Muth, H. W. (1970). Klinische Wochenschrift, 48, 838 .

Lawrence, S. H., and Schulkins, T. (1956). Anesthesiology, 17, 531.

Mullan, D. P. (1969). Studies in Clinical Enzymology. London, Heinemann.

Person, D. A., and Judge, R. D. (1958). Archives of Surgery, 77, 892.

Rehn, J., Koehnlein, E., Graner, S., and Zeller, A. (1960). Medizinische Welt, 7,347 .
Rosalki, S. B, and Wilkinson, J. H (1960) Nature, 188, 1110

Schlief, H., and Kamm, P. (1957). Klinische Wochenschrift, 35, 1083.

Spector, A. A., and Pauli, W. A. (1963). Fournal of Applied Physiology, 18, 818.

Watanabe, R., Kaltus, A. A., and Semenson, C. (1957). fournal of Chronic Diseases, 6, 561 .

Wood, P. (1968). Diseases of the Heart and Circulation, 3rd edn. London, Eyre and Spottiswoode.

\section{Diagnosis of Ruptured Aneurysm of Abdominal Aorta}

\section{J. P. PRYOR}

\author{
British Medical fournal, 1972, 3, 735-736
}

\section{Summary}

A retrospective analysis of 44 cases of ruptured aneurysm of the abdominal aorta showed that only 14 were correctly diagnosed when admitted to hospital. The diagnosis was established in the ward after admission in 14 cases, in the operating theatre in one, and at necropsy in 15. The various clinical presentations are described, since early diagnosis and operation are essential to save life. Awareness of the condition and a careful examination of the abdomen are most important in making the diagnosis.

\section{Introduction}

Death is inevitable after rupture of an abdominal aortic aneurysm unless an operation is performed, and even then half of the patients die (Alpert et al., 1970). The correct diagnosis is often overlooked. Textbooks of medicine and surgery describe the common presentation with abdominal pain, shock, and a pulsatile abdominal mass but give few details of other presentations. Immediate diagnosis and early treatment are essential to save life, and in order to clarify the diagnostic problems we analysed the records of 44 patients with ruptured aneurysm of the abdominal aorta, 41 of whom had been admitted to King's College Hospital since 1958 and the other three were seen at the Brook Hospital in August 1970. Patients with ruptured dissecting or iliac aneurysms were excluded from the review. Seven of the patients were referred from another hospital and only one was moribund on arrival.

\section{Clinical Findings}

The 44 patients were aged 55 to 84 years (mean 70 ) and only five were women. The clinical findings at the time of admission are summarized in Table $I$. Seven of the patients were known to have an aneurysm.

Pain was the most constant feature and was absent in only three patients. In 14 patients the agonizing pain associated with rupture had been preceded by mild backache for up to three weeks. The pain was usually localized to the centre or lower abdomen, though on occasions it closely mimicked ureteric colic or radiated into the thighs. The pain was localized to the left and right sides equally often.

Thirteen patients presented with collapse ranging from a simple faint to a temporary cardiac arrest. These episodes were usually associated with severe pain and the patients often had few other symptoms. Vomiting was seldom severe, though three patients had a haematemesis and one was admitted on account of rectal bleeding. Half of the patients

King's College Hospital, Denmark Hill, London S.E.5 J. P. PRYOR, M.S., F.R.C.S., Senior Surgical Registrar were shocked. In five the tachycardia was masked by slow atrial fibrillation. The systolic blood pressure on admission varied. In 15 patients it was below $80 \mathrm{~mm} \mathrm{Hg}$ and in 10 above $150 \mathrm{~mm} \mathrm{Hg}$.

An abdominal aneurysm was felt in 20 patients but in six of them it was thought to be intact. An additional mass was felt in 16 patients and in nine it was observed to pulsate. In 12 cases the mass was distant from the aorta, and its significance was often overlooked. Some abdominal tenderness was invariable but pronounced muscle guarding occurred in nine patients. In no case were the bowel sounds noted as absent. Abnormalities of the femoral pulses were found in eight patients and absent lower limb reflexes were found in five. Only one patient had an ischaemic leg.

The correct diagnosis was made at the time of admission in only 14 patients, In another 14 it was made after their arrival in the ward, and in one it was made during laparotomy for suspected appendicitis. In the remaining 15 patients the diagnosis was made after death. The main cause for the diagnostic delay in $30(68 \%)$ of the patients was lack of awareness of the variable clinical picture of ruptured aortic aneurysms (see Table II).

Only four of the patients left hospital alive. Of the $\mathbf{4 0}$ who died 14 were operated on and 26 were not. In four of the 26 there was no time for operation, four were unfit for operation, four were "inoperable," and in 14 the diagnosis was not

TABLE I-Symptoms and Signs in 44 Patients with Ruptured Aneurysm of the Abdominal Aorta

\begin{tabular}{|c|c|c|c|c|c|c|}
\hline & & \multicolumn{2}{|r|}{$\begin{array}{l}\text { No. of } \\
\text { Patients }\end{array}$} & \multirow{3}{*}{\multicolumn{2}{|c|}{$\begin{array}{llll}\text { Sweating } & \ldots & \ldots & \ldots\end{array}$}} & $\begin{array}{r}\text { No. of } \\
\text { Patients }\end{array}$ \\
\hline & & & & & & \\
\hline $\begin{array}{l}\text { Abdominal } \\
\text { Back } \quad . .\end{array}$ & • & * & 24 & & . & \\
\hline Lower limb & : & $\because$ & 10 & $<80 \mathrm{~mm} \mathrm{Hg}$ & & \\
\hline Loin . . & . & .. & .. & $>150 \mathrm{~mm} \mathrm{Hg} \ldots$ & $\because$ & \\
\hline Ureteric colic & . & .. & . & Palpable aneurysm & $\because$ & $\therefore$ \\
\hline Absent $\quad \cdots$ & . & . & .. & Other mass $\quad$. . & .. & .. \\
\hline Collapse & & .. & 13 & Abdominal tenderness & .. & 40 \\
\hline Vomiting $\ddot{0}$ & - & .. & 13 & Abdominal guarding & . & . \\
\hline $\begin{array}{l}\text { Haematemesis } \\
\text { Known aneurysm }\end{array}$ & . & .. & . & Abnormal femoral pulses & 3.. & .. \\
\hline r $\quad .$. & • & $\because$ & 35 & Abnormal leg refiexes & & $\cdots$ \\
\hline
\end{tabular}

TABLE II-Clinical Presentations of Ruptured Abdominal Aortic Aneurysm and Diagnostic Errors in 44 Cases

\begin{tabular}{|c|c|c|c|c|}
\hline \multicolumn{2}{|l|}{ Presentation } & \multirow{2}{*}{$\begin{array}{l}\text { No. } \\
18 \\
14\end{array}$} & \multirow{2}{*}{$\begin{array}{c}\begin{array}{c}\text { No. } \\
\text { Incorrectly } \\
\text { Diagnosed }\end{array} \\
4 \\
11\end{array}$} & \multirow[b]{2}{*}{$\begin{array}{l}\text { Aneurysm diagnosed but no rupture } \\
\text { Gastric cancer (2), splenomegaly, hepato- } \\
\text { megaly, renal mass (2), mesenteric cyst, } \\
\text { hvdronephrosis, urinary bladder (2), } \\
\text { diverticular mass }\end{array}$} \\
\hline $\begin{array}{l}\text { Classical } \\
\text { Mass } \ldots\end{array}$ & $\because$ & & & \\
\hline $\begin{array}{l}\text { "Acute } \\
\text { abdomen" }\end{array}$ & . & 26 & 11 & $\begin{array}{l}\text { Perforated duodenal ulcer, pancreatitis (2), } \\
\text { cholecvstitis (2), appendicitis (2), } \\
\text { diverticulitis (3), mesenteric thrombosices }\end{array}$ \\
\hline Collapse & .. & 16 & 9 & $\begin{array}{l}\text { Coronary thrombosis (3), cerebral embolus } \\
\text { (2), bronchopneumonia (2), pulmonary } \\
\text { oedema, pulmonary embolus }\end{array}$ \\
\hline Urological & .. & 15 & 10 & $\begin{array}{l}\text { Loin mass (3), ureteric colic (5), urinary } \\
\text { retention (2) }\end{array}$ \\
\hline $\begin{array}{l}\text { Gastrointestinal } \\
\text { bleeding } \\
\text { Vascular }\end{array}$ & & 5 & 4 & $\begin{array}{l}\text { Gastric erosions, duodenal ulcer (2), } \\
\text { mesenteric thrombosis } \\
\begin{array}{ll}\text { Dissecting aneurvsm } & \text { (2), mesenteric }\end{array}\end{array}$ \\
\hline Neurological & .. & 2 & 2 & $\begin{array}{l}\text { thrombosis (2), iliac artery thrombosis } \\
\text { Cerebral embolus (2) }\end{array}$ \\
\hline
\end{tabular}

